\title{
Applicative Introduction and Development Trend of Roofbolter
}

\author{
Guochen Wen \\ State key laboratory of high \\ performance complicated manufacture, \\ Central South university \\ ChangSha, HuNan, China, \\ 8615116452018
}

\author{
Hua Xiao \\ State key laboratory of high \\ performance complicated manufacture, \\ Central South university \\ ChangSha, HuNan, China, \\ 8615074847926
}

\author{
Hongqiang Zhao \\ ${ }^{1 .}$ State key laboratory of high \\ performance complicated manufacture, \\ Central South university \\ 2. Hunan sunward intelligent equipment \\ Co.Ltd, \\ Changsha Hunan, china, \\ 8613787209741
}

\begin{abstract}
Roofbolter is introduced and classified basing on the different appearances; according to the roofbolter development process in China, roofbolter development history and profiles are summarized; the development and the characteristics in this field of other countries such as Europe and America are described; through comparing, the shortages of domestic roofbolter development are summed up, for example, the bad accessory quality, lacking related standard, the low degree of intelligent; a few corresponding development strategies are suggested about roofbolter development in China.
\end{abstract}

Keywords-roofbolter, mining, project, current situation, development

\section{ROOFBOLTER BRIEF INTRODUCTION AND ITS CLASSIFICATION}

Roofbolter belongs to a rock drilling and pile driving machinery, is the mechanical equipment being used to make bolt supporting. Early roofbolter is mainly used for mine roadway, roof and side bolting; with the development of technology, roofbolter function is increased and the application scope is enlarged remarkably too. Recently it has been applied in construction of anti floating roofbolter, underground continuous wall, soil nailing wall, diaphragm wall, deep foundation pit roofbolter and so on. Roofbolter could achieve the drilling hole as well as the rock drill and down-the-hole drill. It plays an important role in the process of city modernization.

Roofbolter has developed a variety of forms, by the use of field it can be classified into mining roofbolter and engineering roofbolter; wherein the mining roofbolter, according to different structure it can be divided into individual type, skid type, Machine-mounted; according to the power it can be divided into electric driving, pneumatic driving, hydraulic driving; according to the rock broken mode it can be divided into rotary drill, impact drill, impact rotary drill. Roofbolter for engineering, according to different structure, can be divided into skid type, drill vehicle type. And it is usually droved by hydraulic or combined electricity and hydraulic. Modern times, the rock broken mode mainly uses impact rotary, while only rotary or only impact type with a small operation range has been gradually withdrawn from the market.

\section{ROOFBOLTER DEVELOPMENT CONDITION AT HOME AND IN ABROAD}

The mining roofbolter was used in early 1960s, when China began to develop electric drilling of roofbolter, in 1970s imitated by rock drill, YSP45 type telescopic roof drill is developed and it is used to drill mine roof bolt hole. At the same time trolley type roofbolter has also been invested into market. In $1980 \mathrm{~s}$, on the base of overseas roofbolter technology, we developed a half coal rock roof support MZ type and QYM type monomer roofbolter, and began the development of pneumatic roofbolter. In 1990s, domestic pneumatic roofbolter not only could drill holes and bore into sides, but also could have the function of mixing resin, fast mounting bolt. With the development of technology, over the same period it also successfully developed a cantilever tunneling machine supporting roofbolter (i.e. onboard roofbolter) and coal, dig and roofbolter integration unit. After entering twenty-first Century, with the development of hydraulic technology, the appearance of multiple kinds of hydraulic Roofbolter, which structure also appeared a variety of forms, basically have individual and handheld. Currently tunneling roofbolter unit and multiple arm roofbolter are widely used in mining construction. Accompany with the successful development of rock-drilling robot, multiple arm type driving roofbolter is supposed to develop toward automation control.

In the end of $1990 \mathrm{~s}$ and beginning of this century, engineering roofbolter was going to be used in the coastal city. There a few constructions like underground continuous wall and deep foundation pile supporting were finished by using hydraulic crawler type roofbolter that is indraught in some developed countries, which opened the door of using engineering roofbolter in domestic. With the process of city's developing, a lot of engineering stimulated the wide using of roofbolter such as against floating bolter, underground continuous wall, soil nailing wall, diaphragm wall, deep foundation pile roofbolter. And other requirements in construction drove engineering roofbolter development. At 
begins of this century, Beijing Building Research Institute and other companies began to develop the related products, and gradually developed seriation products. Currently Casagrande C6 and Beijing Building Research Institute of MG series roofbolter act the main role in this field. Other domestic engineering machinery companies such as Sany, Xuanhua Oriental Industrial, and Hunan Sunward Intelligent Corporation are gradually developing this kind of machine.

Western developed countries have more mature development of roofbolter, for different application areas they have developed different types. One of Australia's mining pneumatic roofbolter has been in a leading position; the country has 4 major manufacturers, the product characteristics of light weight, low noise, low gas consumption, compact structure. The represented companies are CRAM and ARLMINCO; Finland's Tom Rock products is known by the stable vehicle and excellent quality of roofbolter, which owned wide borehole diameter scope, can realize the mounting bolt and injecting adhesive function. Engineering roofbolters in Europe and the United States have their respective characteristics of the corresponding products. Such as Italy's MAIT400 type drilling machine can achieve the 360 ${ }^{\circ}$ rotary and high rotary speed, Casagrande C6 multi-function drill, which is suitable for multiple soil conditions; Sweden Atlas with wheel type hydraulic roofbolter, which can be automatically controlled and has strong anti-interference performance, Sandvik drill with high efficiency and energy saving features. such as the Caterpillar in the United States, Japanese mine research social strains, German Bauer, soil line sun, Han machine, have related products R \& D . Along with the foreign city construction speed reduction and domestic city construction accelerated, a large number of foreign roofbolter were introduced in domestic market.

\section{PROBLEMS DURING ROOFBOLTER DEVELOPMENT IN CHINA}

\section{A. Unqualified spare parts}

Mechanical parts manufacturing precision is not high, plenty of problems are caused by unqualified relevant parts, some roofbolter problems influenced the speed of engineering and performance. Pneumatic roofbolter due to the above problems often appears unstable air pressure which can not continue normal work, also causing short service life, big noise, and low energy utilization. Hydraulic roofbolter easily come out thermal problems, serious leakage, low reliability, and required pressure can not be reached, for hydraulic components, seals and other quality can not meet the requirement. Drilling rig and pump too heavy, mass oil hoses, many times of energy transformation, result in low efficiency to about $30 \%$.

\section{B. Operators are lacking of professional knowledge, using and maintenance with non-standard measures}

Many roadbed and mine workers without professional training, who operate machines not in the correct procedures and didn't follow the requirement of maintenance; which results in the roofbolter often appearing oil hose rupture, structural damage and function failure, then makes that machinery can not work normally, not only delay construction schedule, reduce construction efficiency, also increased the cost.

\section{Less industry communications and lacking of the related field development standard}

Comparing with overseas advanced technology, domestic technology not only is falling behind, but develop without ordered in recent years, the main reasons are less industry of communications, lack of industry standard, and many components are not unified nomenclature, structure size without rules and standards. There is no systematic development, direction, cause a lot of research go repetitive process even develop relative products without knowing the corresponded existing product technology, waste a lot of energy. No uniform industry standard, parts of the versatility and poor interchangeability are bringing more costing in engineering. Some key spare parts used to be imported, which virtually increase the cost of use.

\section{D.The performance of integrated products technology without substantial improvement, low intelligent level}

Some domestic drills are modified into various roofbolters based on advanced products. Only change made in this process is geometrical parameters, without substantial breakthrough. In foreign countries, has gradually in the study of computer control automatic roofbolter, and making implementation of rock drilling, mounting bolt, injection of binder etc functions bind into one drill. What's more, the realization of the precise positioning and roofbolter hole depth, pore size and high accuracy, greatly improve the engineering quality, operator safety and reduce the labor intensity. According to the different rock rigidity, automatic adjustment to the best performance, achieving a high degree of intelligence; however, domestic research in this area is slow, technologist still stay in the structural modification and improve energy efficiency and other aspects, intelligence research has not been fully carried out.

\section{ROOFBOLTER DEVELOPMENT TREND IN CHINA}

\section{A. To reduce the weight of drill}

Mining drill weight largely determines the operation progress and convenience. By adopting engineering plastics and light glass steel material to reduce weight and enhance the reliability of drilling rig have been developed, will be further attention; and the optimization of structural parameters and high-tech microelectronics technology in different power, different types of roofbolter on the application will greatly reduce mine drilling weight, represent the general trend.

Due to technical limitations, electric roofbolter is less using, while motor driven roofbolter hydraulic, pneumatic drill use high frequency. Solving the core problem of electric drive, to improve their competitiveness, can greatly reduce the volume and weight of mining roofbolter, achieve the advantage that hydraulic, pneumatic drill cannot achieve.

\section{$B$. Strengthen the spares quality during manufacturing}

Along with the deepening of reform and opening up, our country and the international advanced technology exchange gets all-time strengthen, implementing international technical 
standards. Introduction, absorption of foreign advanced design, manufacturing technology and experience, breakthrough in the parts quality, thereby enhance the overall quality of drill. Especially engineering roofbolter parts are mass within compact structure, replacement parts are relatively time-consuming. Parts with high reliability largely determine the service life of the drilling machine and the schedule of project.

\section{Developing multifunctional roofbolter suit to wide rock hardness range}

As a result of roofbolter drilling applications become more and more diversified and complicated, it needs to study a structure that is suitable for general condition of engineering and adapt to different environment operation; optimization of drill structure also can improve the drilling efficiency, avoid the frequent replacement of the drill rod, prolong the service life.

With the domestic mechanization degree is more and more wide and various geology of different city, engineering roofbolter should be applicable to a variety of geology and rock construction. many rigs ( including rock drilling machinery ) although the design is suitable for $\mathrm{F}<10$ or $\mathrm{F} \leq$ 8range, but the actual optimal using condition is less than design; widen roofbolter's working rock hardness range, expand the scope of use should be highlighted by the rig research institutes.

\section{To improve the intelligent level}

Advanced roofbolters in overseas have gradually developed automatic control, highly intelligent technology. The successful research of rock drilling robot would promote the development of the field; man-machine engineering applications lets machines more user-friendly, reduce labor intensity of workers, improve their personal safety will be gradually put on the roofbolter research topic. Its drill rod that could eject itself' and defend being locked will be popular. Ordinary bolt quick installation will gradually realize the intelligent detection and control. At present engineering roofbolter working at construction generally takes along 5 to 6 workers, many working personnel and complicated operation bring more risk to the construction safety and cost. improving the roofbolter's intelligence, such as being able to automatic load and unload pipe, having drill pipe storeroom, with suitable operation platform and simple operation rules, the appropriate operation security system will greatly improve the performance of drilling rig.

\section{CONCLUSION}

Our country's roofbolter is developing uneven, the development of mining roofbolter in drilling machinery could promote roofbolter developing in a successful way without much detour. Many modern cases show that rock drill development has been normalized. And engineering roofbolter research just started, with the domestic city increasing more buildings and modern structure station, which means a large number of mainland city construction needs to use the multi functional roofbolter, and roofbolter demand is also a increasing in many developing countries' city constructions, therefore not only the domestic demand is at a rising period, but the international market is very optimistic. We should hunt for the opportunity to develop relevant reliable, advanced products and keep a highlight on multi functional roofbolter studies.

\section{REFERENCES.}

[1] Atlas Copco. Robot Boomer on Testing. Word Minning Equipment, 1988(3): 35 36

[2] Lutz L.Gergeley p. Mechanics of band and slip of deformed bars in concrete, Journal of Ameican Concrete institute.1967, 64(11):711-721.

[3] Singh S. Cannon H. Multi-resolution planning for earthmoving. Proceedings international conference on robotics and automation .Leuven, Belgium, 1998:198-101

[4] Ouyang Jun. roofbolter status and development direction of our country. Xuzhou, coal mine machinery, 1998, 1

[5] Chen Rongjun, Liang Mingdong, Huang Zhongdong. Analysis of the current situation and development of roofbolter. Shanghai, coal mine machinery, 2001(4)

[6] Shen Shulin, Li Kang. Analysis of roofbolter development situation. Anhui, Huainan Journal of Huainan Vocational Technical College, 2004(1)

[7] Deng Min. Development and application of roofbolter. Chengdu, geological equipment, 2007, 10

[8] Duan Baohong. Coal Mine Roof Bolt Driller actuality and development. Yangquan modern miner, 2008(11)

[9] Jiang Shundong, Guo Chuanxin, Li Li, et al. Roofbolter rig structure characteristics analysis. Beijing construction machinery, 2010(4)

[10] He xi. Bolt supporting technology. in modern mining, 2010, 26(9)

[11] Fang Shanxiong. Bolt support technology and research on construction of deep foundation pit. Fujian construction engineering, 2010(9)

[12] Cheng Liangkui. Rock and soil roofbolter status and development. Beijing Civil Engineering Journal 200134(3) 